\title{
Analisis Pemanfaatan ICT Berdasarkan Gender dalam Menumbuhkan Budaya Literasi
}

Nurdiyana ${ }^{\mathrm{a}, 1 *}$, Suanto ${ }^{\mathrm{b}, 2}$

a,b Program Studi Pendidikan Pancasila dan Kewarganegaraan, Fakultas Keguruan dan Ilmu Pendidikan, Universitas Pamulang

${ }^{1}$ dosen02080@unpam.ac.id; ${ }^{2}$ dosen02190@unpam.ac.id

*korespondensi penulis

Naskah diterima: 12 Agustus 2020, direvisi: 24 Agustus 2020, disetujui: 5 September 2020

\begin{abstract}
Abstrak
Kemajuan Information and Communication Technology (ICT) yang demikian pesat serta potensi pemanfaatannya secara luas telah membuka akses, komunikasi jarak jauh secara langsung maupun tidak langsung yang efektif, dan membuka peluang dalam pendayagunaan informasi secara cepat dan akurat, baik dalam kehidupan sehari-hari maupun dalam mendukung kemajuan pendidikan di Indonesia. Kebutuhan akan ICT dipandang berbeda sesuai kebutuhan dan pemanfaatannya akan berbeda antara laki-laki dan perempuan, begitu pula penggunaannya di dalam proses pembelajaran. Penelitian ini bertujuan untuk menganalisis pemanfaatan dan penggunaan ICT yang dilakukan oleh mahasiswa dan mahasiswi semester 4 Program Studi Pendidikan Pancasila dan Kewarganegaraan Universitas Pamulang. Penelitian ini menggunakan metode penelitian kualitatif yang bersifat deskriptif analisis. Teknik pengumpulan data menggunakan observasi, wawancara, dan dokumentasi penelitian. Adapun informan dalam penelitian ini terdiri dari Ketua Program Studi PPKn, dosen dan mahasiswa semester 4. Hasil penelitian menunjukkan bahwa dalam pemahaman terhadap internet baik oleh mahasiswa dan mahasiswi menunjukkan tingkat perbedaan yang tidak terlalu tinggi, begitu pula dalam pemanfaatan internet sebagai sumber belajar. Mahasiswa dan mahasiswi sering memanfaatkan internet untuk sarana belajar, namun dalam hal penggunaan dalam mencari artikelartikel jurnal, modul digital lebih sering dilakukan oleh mahasiswi, namun perbedaannya tidak terlalu besar
\end{abstract}

Kata-kata kunci: Pemanfaatan ICT, Gender, Budaya Literasi

\section{Abstract}

The rapid advancement of Information and Communication Technology (ICT) and its potential for widespread use has opened up access, direct and indirect effective long distance communication, and opened opportunities for the use of information quickly and accurately, both in everyday life and in everyday life. support the progress of education in Indonesia. The need for ICT is seen as different according to needs and its use will differ between men and women, as well as its use in the learning process. This study aims to analyze the use and use of ICT carried out by students and fourth semester students of the Pancasila and Citizenship Education Study Program at Pamulang University. This research uses qualitative research methods that are descriptive. Data collection techniques using observation, interviews, and research documentation. The informants in this study consisted of the Head of the PPKn Study Program, lecturers and semester 4 students. The results showed that the understanding of the internet by both students and students showed a level of difference that was not too high, as well as the use of the internet as a learning resource. Students and female students often use the internet as a learning tool, but in terms of using it in searching for journal articles, digital modules are more often used by female students, but the difference is not too big..

Keywords: Utilization of ICT, Gender, Literacy Culture 


\section{Pendahuluan}

Pendidikan dapat meningkatkan taraf kehidupan ke arah yang lebih baik. Melalui pendidikan kita dapat merubah kehidupan kita. Kebutuhan akan pentingnya pendidikan tidak hanya milik kaum laki-laki, kaum perempuan memiliki kesempatan yang sama untuk menempuh pendidikan hingga perguruan tinggi seperti kaum laki-laki ( Nurdiyana : 2019).

Dalam Undang-Undang Republik Indonesia No.12 Tahun 2012 Pasal 13 ayat 2 tentang Pendidikan Tinggi berisikan bahwa mahasiswa/i secara aktif mampu mengembangkan potensi dalam pembelajaran, mencari kebenaran ilmiah, penguasaan, pengembangan, pengamalan suatu cabang ilmu pengetahuan dan teknologi untuk menjadi ilmuwan, intelektual, praktisi, dan profesional yang berbudaya. Untuk itu, sarana dalam memperoleh ilmu pengetahuan hanyalah melalui pendidikan. Dari penjelasan tersebut dapat kita simpulkan bahwa setiap mahasiswa harus mampu untuk mengaplikasikan ilmu pengetahuan dan teknologi yang mereka dapatkan untuk dapat mengembangkan kompetensinya.

Kehadiran teknologi dalam kehidupan kita sangatlah berperan penting, bagi seseorang yang masih awam, teknologi sebagai sesuatu yang menyakitkan dan memberatkan bagi mereka, namun bagi mereka yang melek teknologi, hal ini menjadi sesuatu yang yangat bermanfaat bagi kehidupannya. Begitu Pula untuk mahasiswa/i, di era saat ini diharapkan mereka untuk dapat melek teknologi sebagai tuntutan zaman dan mengikuti perkembangan di dalam dunia pendidikan.

Proses pembelajaran merupakan suatu hal yang akan berlangsung secara terus menerus dan berlangsung secara fleksibel mengikuti
Perkembangan ICT tersebut. Perkembangan ICT disambut baik oleh siswa, mahasiswa, guru, dosen dan tenaga pendidik lainnya yang memang merasa terbantu sekali dengan hadirnya ICT di dalam dunia Pendidikan.

Penggunaan ICT dalam kegiatan pembelajaran sudah menjadi bagian yang tidak terpisahkan karena dengan penggunaan ICT kegiatan belajar dapat lebih mudah dilaksanakan sesuai dengan metode dan model pembelajaran yang diinginkan dan dianggap paling efektif.

Menurut Kementerian Negara Riset dan Teknologi, ICT atau yang lebih sering kita dengar dengan istilah TIK (Teknologi, Informasi dan Komunikasi) merupakan bagian dari ilmu pengetahuan dan teknologi yang didefinisikan sebagai segala sesuatu yang berkaitan dengan teknologi yang saling berhubungan dengan pengambilan data sampai ke penyajian data dan informasi tersebut. Selanjutnya, menurut Anatta Sannai dalam Asmani (2011:100) TIK merupakan alat bantu dalam memperoleh pengetahuan antara seseorang kepada orang lain. Perkembangan ICT sudah merambah sampai ke dunia Pendidikan.

Dalam berbagai teori belajar yang sering kita dengar, salah satunya adalah teori dengan pendidikan berbasis digital atau komputer. Dalam berbagai literatur yang terkait dengan pendapat ahli tentang teori belajar, awalnya pemanfaatan media pembelajaran berbasis komputer dalam pembelajaran menggunakan pendekatan teori behaviorisme. Dalam teori ini dijelaskan dimana komputer lebih banyak digunakan untuk melakukan drill and practice. 
Seiring dengan perkembangan yang terjadi, komputer dimanfaatkan untuk membantu siswa menemukan dan merumuskan pengetahuannya melalui interaksi dan eksplorasi sumber-sumber belajar berbasis ICT. Selain itu, pemanfaatan ICT di dalam pembelajaran juga mendukung teori socio constructivism, dimana menurut teori ini, dengan adanya ICT maka dapat memberi pengalaman belajar baru bagi siswa karena siswa dapat belajar secara Bersama dengan melakukan interaksi baik langsung maupun tidak langsung dengan berbagai pihak, baik itu dengan pakar maupun melalui media komunikasi berbasis ICT.

Perkembangan terkini dimana pemanfaatan ICT secara terpadu di dalam pembelajaran yang memadukan berbagai keterampilan dan fungsi ICT di dalam proses belajar mengajar. Penggunaan ICT sebagai media pembelajaran dapat berbentuk file slide powerpoint, gambar, animasi, video, audio, program CAI ( Computer Assisted Instruction ) program simulasi dan lain-lain.

Melalui kemajuan ICT yang berlangsung cepat dimana didalamnya membuka potensi yang bersifat luas dalam pemanfaatan ICT tersebut, sehingganya akses komunikasi saat ini dapat begitu mudah dan terasa dekat. Efektifitasnya sangat terasa sekali di dalam kehidupan manusia. Kemajuan dan perkembangan ICT ini bagai dua sisi mata uang, dapat bermanfaat dengan baik apabila memang benar dalam penggunaannya, namun juga dapat berakibat buruk apabila salah di dalam penggunaannya. Pemanfaatan ICT merupakan faktor yang sangat penting dalam mendukung kemajuan pendidikan di Indonesia.

Kemajuan pesat dalam ICT dan penggunaan potensinya yang luas telah membuka akses, komunikasi jarak jauh yang efektif atau tidak langsung, serta membuka peluang bagi manajemen dan pemanfaatan volume besar informasi dengan cepat dan akurat. Kenyataan menunjukkan bahwa selain dapat berdampak negatif, penggunaan ICT merupakan faktor yang sangat penting dalam mendukung kemajuan pendidikan di Indonesia. Prinsip - prinsip yang perlu diterapkan dalam pemanfaatan ICT (Krisnadi, 2009), yaitu:

1. Dalam memanfaatkan ICT di dalam pembelajaran, hal utama yang perlu diperhatikan adalah karakteristik dari masing-masing pihak, bisa peserta didik, guru dan tenaga kependidikan. sebelum penggunaan ICT tersebut diterapkan secara keseluruhan.

2. Sebelum penggunaan ICT, Langkah awal adalah dengan merancang pemanfaatan ICT tersebut, agar nantinya dapat meningkatkan minat dan motivasi bagi para penggunanya sehingga yang akan tertanam di dalam diri pengguna adalah keinginan untuk meningkatkan kompetensi dirinya baik dari segi intelektual, spiritual, sosial maupun ragawi.

3. Yang perlu juga ditanamkan adalah selain pemanfaatan ICT itu penting, yang utama adalah komunikasi langsung dan interaksi langsung dengan sesame manusia di dalam lingkungan sosial menjadi hal utama yang harus tetap terjalin hal ini berkaitan dengan nilai sosial dan humaniora atau dapat diartikan nilai seni dan budayanya dan kecintaan terhadap alam semesta ini sebagai anugerah yang Tuhan berikan kepada umat-Nya.

4. Dalam hal memanfaatkan ICT hal utamanya atau hal penting yang perlu untuk diperhatikan adalah mereka yang terlibat atau yang menjadi sasaran untuk dapat memberi penghargaan atas kehadiran ICT ini, karena kehadiran ICT ini dapat meningkatkan kompetensi dan 
mengangkat potensi yang dimiliki oleh siswa.

Seiring dengan perkembangan ilmu pengetahuan serta teknologi memberikan dampak yang begitu komplek berkaitan dengan gender. Dampak tersebut dapat kita lihat dalam pemahaman dan pemanfaatan yang dilakukan baik oleh laki-laki maupun oleh perempuan yang berkaitan dengan teknologi dan informasi tersebut.

Penggunaan ICT dalam proses pembelajaran tidak terbatas oleh gender baik laki-laki maupun perempuan, yang menjadi pembeda adalah tergantung pada kebutuhan pengguna. Perbedaan dalam menggunakan ICT dapat dipengaruhi oleh fitur-fitur yang terdapat dalam program ICT dimana fitur-fitur yang dianggap sesuai dengan kebutuhan akan cenderung lebih banyak digunakan. Kemudian yang menjadi fokus permasalahan dalam penggunaan ICT dalam pembelajaran adalah bagaimana pengguna dalam hal ini adalah mahasiswa Program Studi Pendidikan Pancasila dan Kewarganegaraan Universitas Pamulang menggunakan ICT dalam mengembangkan budaya literasi oleh mahasiswa.

Upaya untuk mencapai kemampuan siswa dalam berliterasi, harus diawali dahulu dengan menyiapkan calon guru yang akan membelajarkan literasi tersebut. Mahasiswa (calon guru) harus memiliki seperangkat pengetahuan dan pemahaman yang menyeluruh tentang literasi. Setidaknya kegiatan budaya literasi ini dapat dilakukan oleh mahasiswa, bukan hanya sebagai bekal ilmu, akan tetapi juga sebagai kebiasaan yang harus mereka lakukan sebelum menularkannya pada anak didik mereka nantinya. Pada akhirnya literasi berhubungan dengan keberhasilan seseorang dalam lingkungan masyarakat akademis, sehingga literasi merupakan piranti penting yang harus dimiliki agar dapat meraup kesuksesan dalam lingkungan sosial.

Budaya literasi dapat dibangun melalui berbagai kegiatan pembiasaan membaca dan menulis. Berbagai cara membangun budaya literasi dapat dilakukan di sekolah, perguruan tinggi, maupun di rumah. Hal ini sangat penting, karena seiring dengan perkembangan ICT yang terus mengikuti perkembangan zaman maka semakin sering pula mahasiswa mengakses fitur-fitur yang ada. Kecenderungan menggunakan ICT dalam keseharian mahasiswa akan berpengaruh terhadap budaya literasi.

Seiring dengan perkembangan zaman dan kemajuan dalam bidang teknologi, memberi pengaruh besar terhadap kemampuan literasi seseorang. Dengan beralihnya media membaca dari buku konvensional beralih ke buku digital ini sangat berpengaruh terhadap minat membaca seseorang. Dalam dunia pendidikan tinggi, kecenderungan mahasiswa menggunakan ICT dalam keseharian mereka di lingkungan kampus memberi dampak yang signifikan terhadap minat belajar mereka. Kegiatan pembelajaran menggunakan ICT dapat dilakukan dimana saja dan kapan saja. Dengan teknologi mahasiswa dapat memiliki kemampuan dalam memperoleh berbagai informasi tentang perkuliahan. Pemanfaatan teknologi dalam pembelajaran selaras dengan kajian yang dilakukan Nursyifa (2019) kecanggihan teknologi memudahkan untuk mengakses literasi yang berkaitan dengan pembelajaran, maka atas dasar itulah mahasiswa harus memiliki kompetensi agar dapat menyesuaikan dengan kemajuan teknologi tersebut. 
Penggunaan ICT akan berbeda antara mahasiswa dan mahasiswi, dan hal ini pula yang mempengaruhi kemampuan literasi mereka. Dengan demikian intensitas kegiatan mahasiswa baik yang berkaitan dengan kegiatan bersosialisasi maupun kegiatan yang berkaitan dengan akademik dapat terpengaruh, pengaruh atau dampak penggunaan ICT ini menjadi sorotan dalam proses pembelajaran karena intensitas mahasiswa dalam mengakses fitur-fitur yang tidak berkaitan dengan pembelajaran baik langsung maupun tidak langsung akan mempengaruhi budaya literasi mahasiswa baik melalui membaca atau menulis.

Pendapat yang dikemukakan oleh John M. Echols \& Hassan Sadhily (dalam Rahmawati, 2004: 19), dimana dikemukakan bahwa gender memiliki arti jenis kelamin dalam Bahasa Inggris. Dari pendapat tersebut dapat kita pahami bahwa definisi gender merupakan suatu perbedaan yang akan terlihat antara lakilaki dan perempuan dari sudut tingkah laku dan nilai antara keduanya.

Pendapat berikutnya dari Fakih (2006: 71) mengemukakan bahwa gender dapat dikatakan sebagai suatu sifat yang ada atau melekat baik pada laki-laki maupun pada perempuan yang susunannya dapat dilihat dari keseharian maupun budayanya. Dimana dari pengertian tersebut dapat kita artikan bahwa gender ini memiliki konsep suatu perubahan sifat dan ciri masing-masing yang terjadi dari waktu ke waktu.

Selain itu, Santrock (2003: 365) mengemukakan bahwa istilah gender dan seks memiliki perbedaan dari segi dimensi. Isilah seks (jenis kelamin) lebih menekankan pada dimensi biologis yang terjadi atau yang dialami oleh laki-laki dan perempuan. Sedangkan istilah gender ini, lebih cenderung ke arah perilaku yang dilakukan oleh laki-laki dan perempuan yang ada kaitannya dengan dimensi sosial dan budaya di dalam kehidupan.

Selain itu, istilah gender merujuk pada karakteristik serta ciri-ciri sosial yang ditunjukkan baik oleh laki-laki maupun oleh perempuan. Karakteristik dan ciri yang ditunjukkan ini tidak hanya didasarkan pada perbedaan biologis, melainkan juga pada penerapan dan keberadaannya di dalam lingkungan sosial dan cultural tentang apa artinya menjadi laki-laki atau perempuan (Rahmawati, 2004: 19).

Pendapat dari Moore yang dituliskan oleh Abdullah (2003: 19), dalam tulisannya dikatakan bahwa gender itu berbeda arti dengan seks dan jenis kelamin yang dipandang secara biologis. Istilah gender banyak dikemukakan oleh para ilmuwan sosial bertujuan dalam memberikan penjelasan tentang perbedaan sifat bawaan atau sifat yang memang sebagai anugerah dari sang pencipta serta bentukan budaya antara laki-laki dan perempuan. Gender adalah disini lebih kepada perbedaan peran, fungsi, dan tanggung jawab yang dimiliki oleh laki-laki dan perempuan yang merupakan hasil tatanan sosial dan dapat berubah mengikuti perkembangan zaman. Selanjutnya penjelasan mengenai literasi, dimana literasi merupakan kemampuan berbahasa seseorang seperti menyimak, berbicara, membaca, dan menulis, hasil dari literasi ini agar setiap manusia dapat melakukan komunikasi dengan cara dan kemampuan sesuai dengan apa yang diharapkannya.

Kemampuan membaca dan menulis sangat diperlukan untuk membangun sikap kritis dan kreatif terhadap berbagai fenomena kehidupan yang mampu menumbuhkan kehalusan budi, kesetiakawanan dan sebagai 
bentuk upaya melestarikan budaya bangsa. Sikap kritis dan kreatif terhadap berbagai fenomena kehidupan dengan sendirinya menuntut kecakapan personal (personal skill) yang berfokus pada kecakapan berpikir rasional. Kecakapan berpikir rasional mengedepankan kecakapan menggali informasi dan menemukan informasi.

Kegiatan literasi dapat dilakukan dimanapun, baik di kelas maupun di luar kelas. Pada dasarnya kegiatan literasi bertujuan untuk memperoleh keterampilan informasi, Secara sederhana, literasi dapat diartikan sebagai sebuah kemampuan membaca dan menulis. Selanjutnya budaya literasi adalah untuk melakukan kebiasaan berpikir yang diikuti oleh sebuah proses membaca dan menulis yang pada akhirnya proses kegiatan tersebut akan menciptakan karya (Haryanti, 2014:1).

Menurut Besnier, literasi adalah komunikasi melalui inskripsi yang terbaca secara visual, bukan melalui saluran pendengaran dan isyarat. Inskripsi visual di sini termasuk di dalamnya adalah bahasa tulisan yang dimediasi dengan alfabet, aksara. Salah satu tantangan terbesar dalam pemberdayaan bangsa ini adalah meninggalkan tradisi lisan (orality) untuk memasuki tradisi baca tulis (literacy) (Suroso, 11:2007).

Dengan demikian, penggunaan ICT oleh mahasiswa memiliki pengaruh yang sangat besar terhadap kemampuan literasi mereka, baik kemampuan untuk membaca maupun kemampuan untuk menulis, dan pengaruh tersebut akan berbeda antara laki-laki dan perempuan. Berdasarkan latar belakang masalah yang ada tersebut, perlu kiranya dilakukan tinjauan tentang pemanfaatan ICT berdasarkan sudut pandang gender dalam meningkatkan budaya literasi.

\section{Metode}

Metode yang digunakan di dalam penelitian ini adalah metode penelitian kualitatif yang bersifat deskriptif analitis. Penelitian bertujuan untuk mengetahui seberapa sering teknologi dimanfaatkan oleh gender (mahasiswa laki-laki dan perempuan) sebagai keperluan belajar.

Penelitian ini bertempat di Prodi Pendidikan Pancasila dan Kewarganegaraan (PPKn) Fakultas Keguruan dan Ilmu Pendidikan (FKIP) Universitas Pamulang. Penelitian ini dilakukan dengan metode survey dalam bentuk pengukuran diri sendiri atau selfmeasure. Teknik pengumpulan data yang digunakan dalam penelitian ini meliputi : 1 . Studi dokumen, 2. Observasi, 3. Wawancara pada mahasiswa semester 4 reguler A Program Studi Pendidikan Pancasila dan Kewarganegaraan. Semua data terkait dengan pemanfaatan ICT oleh mahasiswa/I dikumpulkan menjadi satu kesatuan yang kemudian dilakukan analisis data tersebut secara deskripsi.

Dalam analisis data yang dilakukan pada penelitian ini, dimana analisis data tersebut dilakukan dengan proses pengumpulan data. Berdasarkan analisis kualitatif peneliti dapat menarik hasil penelitian berdasarkan data yang ada terkait dengan pemanfaatan ICT oleh mahasiswa/I dalam menumbuhkan budaya literasi.

\section{Hasil dan Pembahasan}

Kehadiran internet di dalam kehidupan membawa dampak pula di dalam pemanfaatannya yang dapat dilihat dari si penggunanya. Berdasarkan sumber data atau informan yang dituju dalam penelitian ini, dimana informan tersebut terdiri atas : Ketua Program Studi PPKn, Sekretaris Prodi, Dosen dan Mahasiswa dan mahasiswi semester 4 
reguler A didapatkan informasi secara riil yang terbagi atas beberapa kategori, yaitu : Pemahaman internet berdasarkan gender dan tujuan penggunaan internet, internet dan budaya literasi.

\section{Pemahaman internet berdasarkan gender dan tujuan penggunaan internet}

Berdasarkan observasi dan wawancara yang dilakukan dengan mahasiswa, peneliti melihat bahwa semuanya sangat memahami internet beserta cara penggunaannya. Berikut transkrip wawancara dengan narasumber :

"Saya sangat senang dengan hadirnya internet dalam kehidupan saat ini, karena dengan adanya internet saya dapat menyelesaikan pekerjaan saya dengan mudah. Internet membantu sekali dalam penyelesaian tugas-tugas yang diberikan oleh dosen." (Wawancara dengan narasumber NK, pada tanggal 21 Mei 2020).

Dari kutipan hasil wawancara di atas, dapat ditarik kesimpulan bahwa baik mahasiswa/I sebagian besar sudah memahami cara penggunaan internet. Kemudian mereka juga sangat merasakan manfaat dari adanya internet tersebut. Mahasiswa dan mahasiswi dapat menyelesaikan tugas-tugas yang diberikan oleh dosen dengan bantuan internet. Berdasarkan data yang diperoleh dari Asosiasi Penyelenggara Jasa Internet Indonesia atau APJII (2018) menunjukkan bahwa hasil survey pengguna internet berdasarkan usia 15-19 mencapai $91 \%$, sedangkan usia 20-24 tahun mencapai $88,5 \%$. Mahasiswa menjadi pengguna internet yang cukup signifikan.

Dalam dunia pendidikan, internet menjadi media yang sangat ideal untuk melakukan kegiatan pembelajaran jarak jauh. Melalui internet ini dapat menghubungkan mahasiswa dan dosen, melihat jadwal kuliah, mengirimkan berkas tugas perkuliahan, melihat nilai, konsultasi, dan melakukan diskusi secara maya.

Pendidikan di masa lalu menempatkan guru sebagai sumber belajar atau belajar yang berpusat pada guru, dimana disini posisi guru adalah sebagai sumber belajar dikarenakan tidak adanya sumber belajar lain yang dapat dijadikan sebagai sumber belajar. Namun seiring berkembangnya dan kemajuan dalam teknologi yang juga dirasakan di dalam dunia Pendidikan, sehingganya memberikan warna dan nuansa baru di dalam dunia Pendidikan. Internet dijadikan sebagai sumber belajar bagi siswa maupun mahasiswa, sehingganya internet ini sebagai sumber belajar baru yang ada dalam proses belajar mengajar antara guru dengan siswa atau antara mahasiswa dengan dosen.

Internet manfaatnya dapat dirasakan pada kemampuan membaca pada seseorang jika memang mereka memanfaatkan internet untuk belajar. Selain itu, kemampuan integrasi seseorang dalam dalam mengevaluasi kredibilitas pada halaman website dapat menjadi meningkat. Hal tersebut mengakibatkan sistem pembelajaran menjadi student center learning (pembelajaran yang berpusat pada siswa, sehingga pelajar khususnya mahasiswa dituntut untuk lebih aktif dalam mencari informasi, data atau bahan bacaan yang berkenaan dengan materi perkuliah.

Berdasarkan kutipan hasil wawancara dengan mahasiswa berinisial RS pada tanggal 23 Mei 2020 mengatakan bahwa " Saya sering memanfaatkan internet sebagai sarana untuk belajar, selain itu saya juga sangat merasakan manfaat internet di dalam perkuliahan, saya dapat menyelesaikan tugas-tugas yang sulit dengan bantuan internet, sehingganya saya dapat mengirimkan tugas-tugas kuliah saya tepat pada waktunya". 
Berdasarkan kutipan wawancara tersebut penulis melihat begitu banyak manfaat positif yang dirasakan oleh mahasiswa dengan adanya internet ini, mereka dapat mengakses internet tanpa dibatasi ruang dan waktu, dan dapat membantu bagi mahasiswa dalam mengerjakan tugas dan menyelesaikan tugas tersebut tepat pada waktunya.

\section{Internet dan Budaya Literasi}

Kehadiran internet di dalam kehidupan manusia memberikan berbagai dampak tergantung bagaimana kita dalam menggunakannya. Dampak ini bagaikan dua sisi mata uang yang berbeda, jika memang penggunaan internet ini sesuai dengan kebutuhan dan digunakan secara bijak maka manfaat baik akan dirasakan bagi para penggunanya, pun sebaliknya jika memang internet tersebut di salah gunakan di dalam pemanfaatannya, maka akan memberikan dampak yang kurang baik bagi mereka yang salah menggunakannya. Sehingganya, penting sekali kedewasaan berpikir dan bijak bagi para pengguna internet tersebut. Sebagian mahasiswa sudah menggunakan internet sesuai dengan kebutuhannya sebagai peserta didik yaitu untuk browsing, resourcing, searching, e-mail dan mailing list (Yunelti, Marjohan, \& Nurfarhana, 2013).

Ada pendapat yang mengatakan bahwa, siapa saja utamanya dalam hal ini adalah mahasiswa yang kesehariannya selalu berhubungan dengan internet untuk menunjang kegiatannya di dalam perkuliahan, dimana internet tersebut sebagai sebuah media yang mereka manfaatkan di dalam pembelajaran, maka dapat dipastikan bahwa mutu dan kualitas pembelajaran mereka dapat menjadi lebih baik. Penggunaan internet sebagai salah satu media pembelajaran yang digunakan di dalam belajar dapat menjadikan proses belajar berlangsung secara mandiri, karena sumber belajar yang mereka gunakan dapat diambil dari internet, pembelajaran tidak lagi berpusat pada guru.

Berdasarkan wawancara dengan dosen pada tanggal 18 Mei 2020, didapatkan keterangan bahwa minat belajar mahasiswa meningkat apabila dosen dalam pembelajaran memanfaatkan teknologi. Penyajian bahan ajar berbasis teknologi dapat menghilangkan kejenuhan belajar mahasiswa, selain itu dosen juga harus mampu menguasai teknologi secara baik.

Bersamaan dengan diberlakukannya pembelajaran secara daring ditengah kondisi pandemi saat ini, baik mahasiswa maupun dosen diharapkan harus mampu menguasai teknologi dengan baik. Pembelajaran jarak jauh yang berlaku hingga saat ini menuntut mahasiswa untuk dapat belajar secara mandiri. Mahasiswa harus mampu mengakses internet sesuai dengan kebutuhan belajar. Pembelajaran jarak jauh yang ada di lingkungan Universitas Pamulang menggunakan media pembelajaran online learning, dimana dalam online learning itu mahasiswa dapat membaca modul yang telah tersedia serta sumber-sumber materi lain yang disajikan dalam tiap-tiap forum elearning.

Terdapat perbedaan dalam pemanfaatan sumber belajar online yang dilakukan oleh mahasiswa dan mahasiswi semester 4 reguler A, dimana mahasiswi lebih senang untuk membaca modul yang tersedia dalam tiap-tiap forum e learning dan mahasiswi lebih sering memanfaatkan internet untuk kebutuhan pembelajaran.

Hasil penelitian ini menunjukkan bahwa pemahaman terhadap internet antara mahasiswa dengan mahasiswi hampir sama, rata-rata mereka paham dan sering menggunakan internet, baik untuk pembelajaran maupun untuk media sosial dan games, namun dalam hal pemanfaatan internet 
seperti mengakses ke $e$-book, modul online dan sebagainya ini lebih banyak dilakukan oleh mahasiswi. Hal ini dapat kita lihat dari ketepatan waktu dalam menyelesaikan tugastugas perkuliahan, rata-rata yang dapat menyelesaikan tugas-tugas tersebut adalah mahasiswi. Mahasiswi senang membaca modul digital yang tersedia untuk tiap-tiap mata kuliah, selain itu mahasiswi juga ketika pembelajaran di kelas dosen memanfaatkan ICT dalam pembelajaran, karena mereka merasakan rasa ingin tahu yang besar terhadap materi jika materi yang disampaikan oleh dosen disajikan dengan memanfaatkan ICT.

\section{Kesimpulan}

Kemajuan teknologi dalam pendidikan membawa dampak yang positif dalam pembelajaran. Hadirnya ICT yang dapat dimanfaatkan untuk memudahkan proses pembelajaran disambut baik oleh mahasiswa. Mahasiswa semester 4 Program Studi PPKn Universitas Pamulang memiliki kemampuan yang baik dalam mengakses dan memanfaatkan internet. Mahasiswa memanfaatkan internet untuk berbagai kebutuhan, antara lain dalam menyelesaikan tugas yang diberikan oleh dosen kepada mahasiswa, ataupun kebutuhan lain yang ada kaitannya dengan perkuliahan, seperti mencari contoh artikel, mencari contoh jurnal dan lain sebagainya. Dengan memanfaatkan ICT tersebut, maka tugas-tugas tersebut dapat diselesaikan tepat pada waktunya.

Hasil penelitian ini menunjukkan bahwa pemahaman terhadap internet antara mahasiswa dan mahasiswi tidak terjadi perbedaan yang cukup tinggi atau signifikan karena antara mahasiswa dan mahasiswi ini memiliki pemahaman yang baik terhadap internet, sehingganya tidak terjadi kesenjangan maupun mendominasi. Ini disebabkan karena kedua gender tersebut berada di dalam lingkungan yang mengharuskan mereka untuk menggunakan teknologi dan mengakses internet yang sama akibat tuntutan maupun kemauan masing-masing. Hanya saja cara mengakses mereka yang berbeda-beda, kebanyakan dari mereka menggunakan android dalam mengakses internet. Selanjutnya, pemanfaatan ICT dalam menumbuhkan budaya literasi didapati bahwa yang sering mengakses internet untuk pembelajaran dan membaca modul-modul digital lebih sering dilakukan oleh mahasiswi, tingkat perbedaannya tidak terlalu besar, hanya kisaran sepuluh persen saja. Oleh karenanya diharapkan kedepannya semua mahasiswa mampu dan tertarik untuk mengakses internet untuk kepentingan perkuliahan, mereka hendaknya diarahkan untuk lebih sering membaca artikel-artikel jurnal untuk dapat menumbuhkan kemampuan literasi membaca dan menulis mahasiswa.

\section{Referensi}

Abdullah, Irwan. (2003). Sangkan Peran Gender. Yogyakarta: Pustaka Pelajar.

APJII. (2018). Survei Penetrasi Pengguna Internet di Indonesia. Diakases pada https://apjii.or.id/survei, pada 1 Agustus 2020.

Asmani, J. (2011). Teknologi Informasi dan Komunikasi dalam Dunia Pendidikan. Yogyakarta: Diva Press.

Fakih. Mansour. (2006). Analisis Gender dan Transformasi Sosial. Yogyakarta: Pustaka Pelajar.

Haryanti, Trini. (2014). Membangun Budaya Literasi dengan Pendekatan Kultural \& Komunikasi Adat. http://www.triniharyanti.id/

Krisnadi. (2009). Rancangan Materi Pembelajaran Berbasis ICT. Jakarta: PT. Gramedia Pustaka Elang 
Nurdiyana, N. (2019). Penyuluhan Pentingnya Pendidikan Untuk Perempuan Millenial. Jurnal Loyalitas Sosial. 1(1), 13-24.

Nursyifa, A. (2019). Transformasi Pendidikan Ilmu Pengetahuan Sosial dalam Menghadapi Era Revolusi Industri 4.0. Jurnal Pendidikan Kewarganegaraan, 6(1), 51-64.

Rahmawati, A (2004). Persepsi Remaja tentang Maskulin dan Feminin Dilihat dari Beberapa Latar Belakangnya. Skripsi pada Jurusan Pendidikan dan Bimbingan UPI Bandung.

Santrock. (2003). Perkembangan Remaja. Edisi keenam. Jakarta: Erlangga
Suroso. (2007). Panduan Menulis Artikel dan Jurnal. Yogyakarta: Elmatera Publishing Yunelti, F., Marjohan, \& Nurfarhanah. 2013. "Penggunaan Internet diKalangan Mahasiswa Jurusan Bimbingan dan Konseling Fakultas Ilmu Pendidikan di Universitas Negeri Padang". Jurnal Konseling, 2 (1): 256-259 